\title{
FAKTOR-FAKTOR DEMOGRAFIK (JENIS KELAMIN, USIA, STATUS PERNIKAHAN, DUKUNGAN DOMESTIK) PENENTU KONFLIK PEKERJAAN DAN KELUARGA DAN INTENSI KELUAR KARYAWAN: STUDI PADA INDUSTRI PERBANKAN INDONESIA
}

\author{
Gugup Kismono \\ Fakultas Ekonomika dan Bisnis Universitas Gadjah Mada \\ e-mail: gugup_kismono@ugm.ac.id, gugupkismono@yahoo.com \\ Reni Rosari, John Suprihanto \\ Fakultas Ekonomika dan Bisnis Universitas Gadjah Mada
}

\begin{abstract}
Involvement in both work and family domain, by men and womesn, may create work and family conflict that induce voluntary turnover. Unfortunately, most studies relating to both voluntary turnover and work and family conflict has been conducted in Western context. This research aims to examine the impact of demographic variables (gender, age, marital status and domestic support) on work and family conflict and turnover intention, undertaken in Indonesia, a country with high score of collectivism and patriarchal culture. The participants $(N=1.122)$ of this research are employees of the Indonesian banking industry which were drawn conviniently. Regression method was utilized to test hypotheses. Results showed that only marital status significantly affect both work to family conflict and family to work conflict. However, marital status did not significantly influence turnover intention. Age significantly, but in opposite direction, influenced turnover intention. This result was unexpected. Theoretical explanation was discussed.
\end{abstract}

Keywords: turnover intention, work to family conflict, family to work conflict, demographic variables.

\begin{abstract}
Abstrak
Keterlibatan laki-laki dan perempuan di dunia kerja dan rumah tangga dapat mungkin menimbulkan masalah serius, yaitu konflik pekerjaan dan rumah tangga yang mendorong terjadinya perputaran karyawan secara sukarela. Sayangnya, kebanyakan riset dilakukan menggunakan latar belakang budaya individualistik. Riset ini bertujuan untuk menganalisis dampak variabel demografik (jenis kelamin, usia, status pernikahan dan dukungan domestik) pada konflik pekerjaan dan rumah tangga dan keinginan keluar dari organisasi/perusahaan. Riset dilakukan di Indonesia, negara dengan budaya patriarkal dan kolektivistik. Partisipan riset ini adalah karyawan bank-bank berjumlah 1.122 orang yang penyampelannya dilakukan secara tidak acak. Analisis regresi dilakukan untuk mengetes hipotesis. Hasil penelitian menunjukkan bahwa hanya status pernikahan yang berpengaruh signifikan pada dua jenis konflik: konflik pekerjaan ke rumah tangga dan konflik rumah tangga ke pekerjaan. Status pernikahan berpengaruh tidak signifikan pada intensi keluar karyawan. Umur berpengaruh signifikan, namun berlawanan arah dari hipotesis, pada intensi keluar karyawan. Penjelasan hasil penelitian secara teoritis didiskusikan di artikel ini.
\end{abstract}

Kata kunci: intensi keluar, konflik pekerjaan ke rumah tangga, konflik rumah tangga ke pekerjaan, variabel demografik.

\section{PENDAHULUAN}

Para manajer bisnis di Indonesia menghadapi permasalahan serius terkait rendahnya tingkat komitmen para karyawan terhadap organisasi mereka. Survei yang dilakukan oleh WatsonWyatt (2005) menunjukkan bahwa hampir seperempat dari 8.690 karyawan Indonesia yang berpartisipasi dalam survei, termasuk di perusahaan perbankan, dilaporkan memiliki 
kesiapan untuk keluar dari organisasi jika ada kesempatan. Pada survei lain yang dilakukan oleh Hay Group yang melibatkan 42 perusahaan (termasuk 9 bank) menunjukkan bahwa secara keseluruhan indeks komitmen karyawan Indonesia hanya sebesar 69\% (Pambudi, 2007). Tingkat indeks komitmen secara keseluruhan yang rendah ini menunjukkan bahwa perusahaan-perusahaan Indonesia sedang menghadapi risiko kehilangan para karyawan kompeten mereka disebabkan oleh turnover sukarela (voluntary turnover).

Selain dihadapkan pada tingginya tingkat keinginan keluar dari karyawan, perusahaan-perusahaan Indonesia juga dihadapkan pada terbatasnya jumlah ketersediaan karyawan yang qualified atau memenuhi syarat (Ilwan dan Widodo, 2008; Pambudi, 2007; Rahayu, 2006; Winasis et al., 2007) untuk mendukung pertumbuhan bisnis mereka. Permasalahan ini merata terjadi juga di industri perbankan. Mengelola turnover karyawan menjadi proses penting bagi bank-bank di Indonesia sebab dengan turnover sukarela yang terlalu tinggi tentunya akan mengakibatkan kinerja organisasional menjadi semakin rendah (Dess and Shaw, 2001; Ilwan dan Widodo, 2008; Koys, 2001; Pinkovitz, Moskal and Green, 2004; Rahayu, 2006). Oleh karena itu, manajemen turnover sukarela karyawan yang efektif menjadi suatu keharusan dalam permasalahan ini.

Akan tetapi, upaya untuk membatasi turnover sukarela dalam banyak konteks terhalang oleh pemahaman yang tidak lengkap terhadap alasan-alasan yang mendasari para karyawan untuk meninggalkan pekerjaan mereka secara sukarela (Maertz and Griffeth, 2004; Mitchell et al., 2001). Pada literatur yang ada, misalnya, terungkap bahwa perhatian terhadap pengaruh demografik, termasuk usia, jenis kelamin, menikah, jumlah anak, dan dukungan domestik pada konflik pekerjaan dan keluarga dan intensi keluar masih terbatas diberikan. Di Indonesia, sejauh pengetahuan peneliti masih sangat terbatas publikasi ilmiah terkait dengan hal tersebut.

Kebanyakan penelitian berkaitan dengan konflik pekerjaan dan keluarga dan intensi keluar dilakukan di Negara-negara Barat yang memiliki konteks budaya individualis secara dominan (Hofstede, 2001; Oyserman, Coon and Kemmelmeier, 2002), khususnya Amerika Serikat. Hofstede (2001) meng- golongkan Amerika Serikat sebagai salah satu negara yang memiliki rangking tertinggi untuk 'individualisme' di dunia, dengan nilai 91. Sebagai perbandingan, Hofstede menggambarkan Indonesia sebagai Negara dengan nilai terendah untuk 'individualisme' (14 dari 100). Nilai rendah untuk Indonesia terkait dengan individualisme tersebut mendukung ide bahwa negara ini adalah masyarakat 'collectivist' (Hofstede, Hofstede and Minkov, 2010; Oyserman, Coon and Kemmelmeier, 2002).

Telaah literatur untuk penelitian ini juga mengungkapkan bahwa dalam masyarakat individualis kerja dan keluarga dipandang sebagai independen, bidang yang berbeda (Spector et al., 2007; Yang et al., 2000) yang bersaing untuk sumberdaya yang sama (waktu, upaya dan energi). Ketika tuntutan kerja mengganggu kebutuhan individu untuk melaksanakan tanggungjawab keluarga, maka konflik kerja keluarga terjadi. Sebaliknya, di masyarakat yang lebih kolektivis, kerja dan keluarga dipersepsikan menjadi domain interdependen; yaitu kerja dilihat sebagai kontribusi untuk keluarga, daripada bersaing dengan keluarga (Lu et al., 2006; Spector et al., 2007).

Selain itu, menjadi sesuatu yang umum di Indonesia untuk memiliki bantuan domestik (Friedman and Greenhaus, 2000) dari keluarga atau pembantu rumah tangga yang melaksanakan kegiatan-kegiatan rumah tangga seperti mengasuh anak, memasak dan menjaga rumah. Praktek-praktek seperti ini, memberikan dukungan pada para karyawan, dengan membebaskan waktu mereka yang akan dialokasikan untuk rumah dan keluarga (Friedman and Greenhaus, 2000).

Laki-laki dan perempuan mungkin juga berbeda dalam hal pengalaman konflik pekerjaan dan keluarga. Masyarakat Indonesia masih cenderung mempersepsikan bahwa peran ideal perempuan adalah di rumah. Sedangkan peran ideal laki-laki adalah sebagai kepala keluarga yang memiliki kuajiban untuk mencari nafkah dan menghidupi keluarga. Dengan demikian, perempuan yang bekerja di luar rumah lebih rentan mengalami konflik pekerjaan dan keluarga dibanding laki-laki. Sebaliknya, karena peran ideal laki-laki adalah di kantor, maka kegiatan rumah tangga lebih mudah mengganggu peran di domain pekerjaan. Status pernikahan akan menambah kompleksitas perempuan yang bekerja. 
Norma-norma budaya ini dan dukungan-dukungan terkait pekerjaan domestik mungkin memiliki konsekuensi yang berpengaruh terhadap hubungan antara turnover sukarela dan konflik pekerjaan dan keluarga di masyarakat Indonesia. Temuan penelitian tentang hubungan antara variabel-variabel mungkin robust di budaya 'individualistik' Barat, tetapi mungkin tidak dapat serta merta diaplikasikan di konteks budaya kolektivis Indonesia. Untuk membuktikan proposisi awal ini, pengaruh demografik (usia, jenis kelamin, menikah, jumlah anak dan dukungan social) terhadap konflik pekerjaan dan keluarga dan intensi keluar di konteks budaya kolektivis Indonesia diuji dalam penelitian ini.

\section{Konflik Pekerjaan dan Keluarga, Intensi Keluar dan Variabel Demografik}

Para pekerja sering dihadapkan pada berbagai tantangan dalam mengelola pekerjaan mereka, peran dalam keluarga mereka, dan yang lebih penting lagi, pada saat ini tantangan-tantangan tersebut menjadi lebih beragam dan kompleks. Fokus terhadap isu-isu pekerjaan-keluarga dan praktek-praktek pekerjaan-keluarga terutama sekali diarahkan oleh sejumlah perubahan utama demografik. Termasuk diantaranya peningkatan jumlah pekerja perempuan (Miliken et al., 1998), peningkatan jumlah pasangan bekerja (dual-career couples) dan keluarga orang tua tunggal (single-parent family) (Goodstein, 1994), dan peningkatan jumlah populasi orang tua (Hendrickson, 2000).

Di masyarakat Indonesia, laki-laki dan perempuan dipersepsikan untuk memenuhi peran yang berbeda di tempat kerja dan di rumah (Soetjipto, 2004; Wedhaswary, 2008). Oleh karena itu, perbedaan peran ini mungkin menciptakan perbedaan keterikatan mereka, laki laki mungkin sangat terikat terhadap kerja sementara perempuan mungkin sangat terikat terhadap keluarga. Perbedaan "area" terhadap keterikatan ini mungkin menghasilkan perbedaan antara laki-laki dan perempuan terkait konflik kerja keluarga dan intensi keluar yang disebabkan oleh konflik tersebut.

Konsep-konsep konflik pekerjaan dan keluarga dan intensi keluar dan pengaruh demografik pada variabel-variabel tersebut secara ringkas dijelaskan berikut ini. Telaah singkat literatur tentang konflik pekerjaan dan keluarga, turnover intention dan pengaruh demografik di budaya patriarki juga dipaparkan berikut ini.

\section{Konflik Pekerjaan dan Keluarga: Konflik Pekerjaan-Keluarga (KPK) dan Konflik Keluarga-Pekerjaan (KKP)}

Konflik pekerjaan dan keluarga didefinisikan sebagai bentuk konflik antar peran (inter-role conflict) di mana tekanan peran dari domain kerja dan keluarga tidak cocok satu sama lain untuk beberapa hal (Greenhaus and Beutell, 1985). Ketika harapan kerja dan keluarga berada dalam konflik, kerja mungkin dipersepsikan mengganggu kepuasan dan kesenangan keluarga; atau sebagai kemungkinan lain, tekanan keluarga mungkin mengganggu kepuasan dan sukses yang dipersepsikan di tempat kerja (Friedman and Greenhaus, 2000).

Telaah literatur untuk penelitian ini mengungkapkan bahwa ketika individu terlibat dalam peran baik kerja maupun keluarga (peran ganda/multiple roles), peran-peran ini mungkin menghabiskan sumberdaya (usaha, waktu, dan energi), menghasilkan konflik antar peran. Jumlah waktu yang dicurahkan untuk tuntutan dari satu peran menghabiskan waktu yang dibutuhkan untuk memenuhi tuntutan peran yang lain. Selanjutnya, ketika tuntutan kerja dan keluarga berada dalam konflik, pemanfaatan sumberdaya pada domain satu membutuhkan pengorbanan dari domain yang lain.

Para peneliti (Frone, Russell and Cooper, 1992; Gutek, Searle and Klepa, 1991; Netemeyer, Boles and McMurrian, 1996) mengakui dualitas dari konflik pekerjaan dan keluarga dengan mempertimbangkan kedua arah konflik tersebut: kerja mengganggu keluarga (KPK dan keluarga mengganggu kerja (KKP. Kedua variasi konflik pekerjaan dan keluarga ini merupakan bidang berbeda dari kehidupan seseorang (Mesmer-Magnus and Viswervaran 2005).

\section{Konflik Pekerjaan-Keluarga (KPK)}

Konflik Pekerjaan-Keluarga (KPK) menunjukkan gangguan yang dipersepsikan karyawan dari aktivitas-aktivitas yang terkait dengan kerja ke dalam pemenuhan tanggungjawab keluarga (Netemeyer, Boles and McMurrian, 1996). Telaah literatur untuk penelitian ini mengungkapkan bahwa KPK mungkin dipengaruhi oleh keterikatan atau kelekatan 
karyawan pada pekerjaan mereka. Para karyawan yang terikat kuat dengan pekerjaan (highly embedded employees) mungkin menghabiskan lebih banyak waktu dan energi pada pekerjaan mereka, menghasilkan beban kerja berlebihan yang memunculkan stres kerja, dengan akibat selanjutnya gangguan kerja terhadap kehidupan keluarga para karyawan.

\section{Konflik Keluarga-Pekerjaan (KKP)}

Konflik Keluarga-Pekerjaan (KKP adalah konflik antar peran (inter-role conflict) di mana tuntutan waktu dicurahkan untuk, dan ketegangan yang diciptakan oleh, keluarga yang dipersepsikan oleh para karyawan mengganggu tanggung jawab terkait pekerjaan (Gutek, Searle and Klepa, 1991; Hammer et al., 2005; Netemeyer, Boles and McMurrian, 1996). Keluarga mengganggu pekerjaan mungkin terjadi sebagai hasil dari keterlibatan karyawan yang tinggi pada kegiatan-kegiatan keluarga atau komunitas. Oleh karena itu, KKP mungkin dihasilkan dari keterikatan karyawan yang tinggi pada keluarga.

Telaah literatur untuk penelitian ini juga menunjukkan bahwa keberadaan KPK mungkin mengindikasikan bahwa peran kerja mengganggu kepuasan dan kesuksesan dalam keluarga. Lebih lanjut, kegiatan-kegiatan keluarga mungkin mengganggu kepuasan dan kesuksesan di tempat kerja (Friedman and Greenhaus, 2000; Greenhaus and Powell, 2006). Oleh karena itu, KPK kemungkinan menghasilkan konsekuensi-konsekuensi negatif seperti stres dan ketidakbahagiaan, dan sebagai konsekuensinya meningkatkan intensi keluar (Eby et al., 2005; Kossek and Ozeki, 1999).

Dalam konteks budaya kolektivis, pekerjaan merupakan sesuatu yang berpengaruh penting pada keluarga (Hofstede, Hofstede \& Minkov, 2010; Spector et al., 2007). Status sosial sangat mungkin terbentuk karena keberhasilan seseorang di pekerjaan mereka. Oleh karena itu, keterikatan seseorang pada pekerjaan mengindikasikan kesuksesan karir yang harus terus diperjuangkan. Dengan demikian, KPK bisa dipersepsikan positif. Tingkat KPK yang tinggi sangat mungkin justru dianggap positif. Sebaliknya, KKP bisa mengancam kesuksesan karir seseorang dan oleh karenanya maka harus ditekan serendah mungkin. Namun demikian, riset-riset yang dilakukan di beberapa negara kolektivis seperti China dan Taiwan menemukan perbedaan yang tidak signifikan dibandingkan dengan negara-negara individualis (Spector et al., 2007; Spector et al., 2004).

\section{Intensi Keluar}

Intensi keluar mencakup intensi, keinginan dan rencara karyawan untuk meninggalkan organisasi (Guimaraes and Igbaria, 1992; Williams and Hazer, 1986). Istilah ini mungkin juga memasukkan persepsi dan evaluasi individu tentang alternatif pekerjaan (Mobley et al., 1979). Intensi keluar ditemukan secara konsisten menjadi anteseden terkuat dari pengunduran diri secara sukarela (voluntary turnover) (Breukelen, Vlist and Steensma, 2004; Hayes et al., 2006; Michaels and Spector, 1982; Mobley et al., 1979; Steel and Ovalle, 1984; Thatcher, Stepina and Boyle, 2002). Turnover sukarela merupakan tindakan yang diinisiasi oleh karyawan untuk meninggalkan organisasi. Dapat diasumsikan bahwa meninggalkan organisasi secara sukarela merupakan hasil dari proses pembuatan keputusan yang rasional. Para karyawan mempertimbangkan intensi dan keinginan mereka untuk meninggalkan pekerjaan, dan menemukan kesempatan untuk mendapatkan kondisi yang lebih baik sebelum turnover sukarela terjadi. Para karyawan dengan tingkat intensi keluar yang tinggi akan lebih mungkin untuk meninggalkan organisasi mereka dibanding dengan mereka dengan tingkat intensi keluar yang rendah. Oleh karena itu, intensi keluar merupakan proxy yang valid untuk merepresentasikan turnover sukarela (Pasewark and Viator, 2006; Price, 2004).

\section{HIPOTESIS PENELITIAN}

Terdapat empat hipotesis utama yang dibuktikan secara empiris menggunakan data yang telah terkumpul. Variabel-variabel konflik pekerjaan dan keluarga serta intensi keluar diteliti hubungannya dengan jenis kelamin, usia, status pernikahan dan dukungan domestik. Hipotesis penelitian disusun berdasarkan pada mekanisme psikologis (theoretical relationship) seperi paparan berikut.

\section{Jenis Kelamin (Gender), KPK, KKP dan Intensi Keluar}

Studi tentang gender di dalam organisasi telah menarik minat para peneliti, tetapi hasilnya 
bertentangan satu sama lain. Misalnya, Steers dan Rhodes (1978) dan Watson (1981) menemukan bahwa para karyawan perempuan absen dari kerja lebih banyak daripada laki-laki. Penelitian oleh van der Velde (2003) menunjukkan laki-laki memiliki komitmen organisasional lebih tinggi. Penelitian lebih lanjut oleh van der Velde, Bossink and Jansen (2005) menemukan para karyawan laki-laki lebih mau untuk menerima penugasan luar negeri dan lebih mau untuk mengikuti istri mereka ke luar negeri untuk bekerja, dibanding rekan-rekan perempuan mereka. Dalam kaitannya dengan variabel intensi keluar, Russ and McNeilly (1995) memperlihatkan bahwa gender memoderasi pengaruh komitmen organisasional pada intensi keluar. Sebaliknya, Rosin and Korabik (1995) menyatakan tidak ada perbedaan dalam kontribusi gender terhadap intensi untuk keluar. Griffeth, Hom and Gaertner (2000) mendukung penemuan bahwa perempuan dan laki-laki memiliki tingkat turnover yang sama.

Peningkatan partisipasi perempuan di dunia kerja dan keluarga-keluarga pencari nafkah tunggal (single earner families) telah mengubah peran gender di banyak aspek kerja seperti tingkat okupasi (level of occupation), jam kerja per minggu, skedul pekerjaan, demikian juga dengan situasi keluarga (Byron, 2005; Kinnunen, Geurts and Mauno, 2004). Partisipasi perempuan di pekerjaan-pekerjaan yang dibayar semakin meningkat secara signifikan. Tuntutan peran baru juga dialami oleh laki-laki di mana mereka menjadi lebih terlibat dengan keluarga mereka. Oleh karena itu, laki-laki dan perempuan berbagi pengalaman yang sama di banyak aspek kerja dan situasi keluarga. Perubahan norma-norma dan sikap terhadap karyawan perempuan di sebagian besar negara-negara Barat telah mengubah hubungan antara kerja dan keluarga (Kinnunen, Geurts and Mauno, 2004). Laki-laki dan perempuan juga ditemukan memiliki perasaan yang sama terhadap KPK (Cinamon and Rich, 2002).

Di Indonesia, budaya patriarki mengasumsikan laki-laki menjadi pemimpin dan pembuat keputusan utama, di arena baik publik maupun domestik (Siahaan, 2003). Mereka dianggap bertanggungjawab terhadap kesejahteraan keluarga. Menginvestasikan lebih banyak waktu di tempat kerja dianggap pantas bagi laki-laki karena mereka berusaha bertanggungjawab yang selanjutnya investasi tersebut akan berpengaruh positif pada kesejahteraan keluarga mereka. Sebagai konsekuensinya, laki laki mungkin mempersepsikan bahwa komitmen yang tinggi atau keterikatan pada kerja tidak mengganggu keluarga, hal yang sama mungkin tidak terjadi pada perempuan. Perempuan tidak didorong untuk mengambil peran aktif di kegiatan-kegiatan yang dibayar dalam domain publik, tetapi diharapkan lebih baik untuk menggunakan waktu mereka terutama di rumah tangga pada kegiatan-kegiatan yang tidak dibayar, yaitu di domain privat (Siahaan, 2003). Akibatnya, perempuanperempuan kemungkinan memiliki kelekatan lebih besar pada domain bukan-kerja atau keluarga dibanding rekan kerja laki-laki mereka. Lebih komit pada rumah tangga mungkin tidak menghasilkan KKP yang lebih tinggi bagi perempuan. Tetapi, sebaliknya, menginvestasikan waktu lebih banyak pada rumah tangga akan menghasilkan KKP yang lebih tinggi pada laki-laki.

Dengan demikian, di budaya patriarki Indonesia yang kental (Wedhaswary, 2008), gender mungkin berpengaruh pada konflik pekerjaan dan keluarga, baik berupa KPK maupun keluarga-pekerjaan, dan intensi keluar. Meskipun perempuan-perempuan memiliki kesempatan yang semakin meningkat untuk mengembangkan karir mereka di domain publik, gaji dari pekerjaan (profesional) mereka dianggap hanya sebagai penghasilan tambahan bagi keluarga; peran utama mereka dipersepsikan tetap berada di rumah. Sebagai konsekuensinya, perempuan-perempuan dipandang lebih cocok terlibat secara intens pada keluarga mereka dan laki-laki terlibat secara intens di karir mereka.

Permasalahan-permasalahan KPK serta intensi keluar oleh karena itu diperkirakan menjadi semakin besar terjadi pada para karyawan (perempuan) yang terlibat kuat pada keluarga mereka dibanding bagi mereka yang secara relatif kurang terlibat. Dengan alasan tersebut, pada penelitian ini, KPK dan intensi keluar diperkirakan menjadi lebih tinggi pada perempuan dibanding pada laki laki. J ika lakilaki lebih terlibat dalam karir mereka, tanggungjawab keluarga mungkin dipersepsikan sebagai bukan pokok bagi peran utama mereka. Oleh karena itu, KKP dan intensi keluar diperkirakan menjadi lebih tinggi pada laki-laki dibandingkan perempuan. 
Argumentasi di atas mengarahkan penelitian ini untuk menguji hipotesis berikut:

H1 : Jenis kelamin berhubungan positif dengan KPK KKRlan intensi keluar.

H1a : Jenis kelamin berhubungan positif dengan KPK.

H1b : Jenis kelamin berhubungan positif dengan KKP.

H1c : Jenis kelamin berhubungan positif dengan intensi keluar.

\section{Usia, Konflik Pekerjaan-Keluarga, KKP} dan Intensi Keluar

Menurut banyak model karir, individu mungkin melihat karir mereka secara berbeda tergantung pada di mana mereka berada pada tahapan karir-terkait usia (Viega, 1983). Para peneliti telah mengamati bahwa, pada tahap awal karir, para individu sering menginginkan atau mau untuk mengorbankan kehidupan personal mereka demi kepentingan kemajuan karir mereka (Gordon \& Whelan-Berry, 2007). Tetapi, selama para individu berkembang dalam usia pada tahapan kematangan karir mereka, mereka menemukan untuk lebih besar menekankan pada keseimbangan antara kerja dan kehidupan keluarga mereka ketika menilai karir mereka. Oleh karena itu, karena semakin besar prioritas yang individu berikan untuk peran keluarga mereka dengan semakin bertambahnya usia, kepuasan karir dari individu yang lebih tua kemungkinan menjadi semakin negatif dipengaruhi oleh KPK dibandingkan dengan para individu yang lebih muda. Berdasarkan tahapan karir, semakin tua usia seorang karyawan maka akan semakin sensitif terhadap konflik antara pekerjaan dan keluarga, dalam bentuk KPK maupun KKP, yang dialaminya. Demikian juga dengan intensi keluar.

Penjelasan teoritis di atas menjadi dasar hipotesis yang akan diuji menggunakan data penelitian ini.

$\mathrm{H} 2$ : Usia berhubungan positif dengan KPK KKRlan intensi keluar.

$\mathrm{H} 2 \mathrm{a}$ : Usia berhubungan positif dengan KPK. $\mathrm{H} 2 \mathrm{~b}$ : Usia berhubungan positif dengan KKP.

$\mathrm{H} 2 \mathrm{c}$ : Usia berhubungan positif dengan intensi keluar.

\section{Status Pernikahan, KPK, KKP dan Intensi Keluar}

Peelitian terdahulu menemukan bahwa per nikahan mengarahkan para individu untuk memberikan prioritas kehidupan personal mereka lebih tinggi dibandingkan pada kehidupan kerja mereka (Blau et al., 1998). Hal yang sama mungkin juga terjadi terkait dengan peran sebagai orang tua, bahwa menjadi orang tua meningkatkan pentingnya para individu terhadap peran keluarga mereka (Blau et al., 1998). Disebabkan oleh semakin besar prioritas yang para individu berikan kepada peran keluarga mereka ketika mereka menikah dan/atau memiliki anak, mereka mungkin lebih sensitif pada aktivitas-aktivitas pekerjaan yang membutuhkan waktu dan energi yang menyebabkan peran kerja mereka mengganggu (spill over) peran keluarga. Oleh karena itu, individu yang menikah diperkirakan memiliki tingkat konflik pekerjaan dan keluarga yang lebih tinggi dibandingkan mereka yang belum menikah. Tingkat konflik pekerjaan dan keluarga yang dialami individu potensial menumbuhkan stres dan ketidaknyamanan kerja. Intensi keluar mungkin juga meningkat. Individu yang menikah, dengan demikian, memiliki intensi keluar lebih tinggi.

Proposisi yang dibangun secara teoritis di atas akan diuji menggunakan data empiris. Hipotesis yang dikembangkan adalah:

H3 : Status pernikahan berhubungan positif dengan KPK KKRlan intensi keluar.

$\mathrm{H} 3 \mathrm{a}$ : Status pernikahan berhubungan positif dengan KPK.

$\mathrm{H} 3 \mathrm{~b}$ : Status pernikahan berhubungan positif dengan KKP.

$\mathrm{H} 3 \mathrm{c}$ : Status pernikahan berhubungan positif dengan intensi keluar.

\section{Dukungan Domestik, KPK, KKP dan Intensi Keluar}

Dukungan domestik dalam hal ini merupakan keberadaan bantuan yang dapat meningkatkan ketahanan individu dalam menghadapi masalah atau tekanan kerja. Dukungan domestik dapat bersumber utamanya dari keluarga, teman, asisten keluarga (pembantu). Menurut Parasuraman et al. (1992), dukungan domestik ini dapat mengurangi pengaruh stres yang berkaitan dengan pekerjaan dan burnout dari pekerja. Cohen and Syme (1985) dan Lambert (2000) menambahkan bahwa dukungan domestik berperan mengatasi, meredakan dan menghindari peristiwa-peristiwa yang dialami individu yang berpotensi menimbulkan stress. Penelitian yang dilakukan oleh Lingard and Francis (2006) menemukan bahwa hubungan 
sosial dapat mengurangi stres yang diakibatkan KPK Cohen and Syme (1985) menjelaskan bahwa dukungan domestik yang diterima oleh seseorang merupakan cara coping dalam menghadapi stres yang dialami. Individu yang mendapatkan dukungan domestik akan merasa memiliki kekuatan untuk mendapatkan solusi dari segala permasalahan yang dihadapi. Cohen and Syme (1985) lebih lanjut menjelaskan bahwa sebagai sumber coping dukungan domestik juga berpotensi membantu individu mengurangi pengaruh negatif yang muncul akibat kondisi stres yang dialami. Pengaruh negatif akibat stres dapat berupa permasalahan psikologikal/sikap, keperilakuan, kognitif, dan kesehatan fisik. Penelitian yang luas mendukung pengaruh negatif dari stres yang dipersepsikan pada banyak aspek dalam kehidupan kita (Kreitner and Kinichi, 2011). Stres di tempat kerja berhubungan secara negatif terhadap kepuasan kerja, komitmen organisasional, perilaku kewargaan organisasional, emosi positif dan kinerja, dan secara positif dengan kelelahan emosional, absensi, dan turnover.

Dalam konteks dukungan domestik terkait dengan konflik pekerjaan dan keluarga, keberadaan keluarga, pembantu, dan teman dapat menjadi buffer pengaruh negatif konflik pekerjaan dan keluarga pada berbagai aspek perilaku karyawan. Karyawan yang tidak memiliki dukungan domestik akan lebih sensitif terhadap konflik pekerjaan dan keluarga sehingga tingkat KPK,KKP serta intensi keluar lebih tinggi dibanding mereka yang memiliki dukungan domestik.

Argumentasi teoritik di atas dibuktikan secara empiris dalam penelitian ini dengan berpedoman pada proposisi berikut:

H4 : Dukungan domestik berhubungan positif dengan KPK, KKPlan intensi keluar.

H4a : Dukungan domestik berhubungan positif dengan KPK.

$\mathrm{H} 4 \mathrm{~b}$ : Dukungan domestik berhubungan positif dengan KKP.

$\mathrm{H} 4 \mathrm{c}$ : Dukungan domestik berhubungan positif dengan intensi keluar.

\section{METODE PENELITIAN}

\section{Alat Ukur}

Penelitian ini menganalisis hubungan berbagai variabel, yaitu KPK, KKP, Intensi Keluar, jenis kelamin, usia, status pernikahan, dan dukungan domestik. Variabel KPK dan KKP diukur menggunakan skala yang dikembangkan oleh Netemeyer, Boles and McMurrian (1996). Item untuk mengukur KPK dan KKP masing-masing terdiri atas lima pertanyaan. Sedangkan alat ukur intensi keluar (tiga item pertanyaan) dikembangkan dari skala Mobley, Horner and Hollingsworth (1978), dan dukungan domestik mengadopsi konsep Friedman dan Greenhaus (2000). Validitas alat ukur dianalisis menggunakan convergent validity. Sedangkan reliabilitas diukur menggunakan internal konsistensi yang ditunjukkan oleh Cronbach Alpha dan Corrected Item-Total Correlation. Hasil convergent validity menunjukkan nilai factor loadings berkisar antara 0,704 (KPK item nomor 5) dan 0,947 (KPK item nomor 4). Cronbach alpha paling rendah 0,885 (intensi keluar) dan corrected item-total correlation paling kecil 0,696 (KPK item nomor 5).

\section{Skala Pengukuran}

Jenis skala dalam penelitian ini tidak seragam. Variabel KPK, KKP, Intensi Keluar dan Usia menggunakan skala ordinal, yaitu satu (sangat tidak setuju) sampai dengan enam (sangat setuju). Sedangkan jenis kelamin, status pernikahan dan dukungan domestik menggunakan skala nominal (satu dan dua). Perbedaan skala ini diakomodasi pada teknik analisis regresi yang dilakukan.

\section{Prosedur Pengumpulan Data}

Partisipan penelitian ini adalah karyawan bank di Indonesia dengan status hubungan kerja "kontrak permanen", yaitu mereka yang selama ini dikenal dengan sebutan karyawan tetap. Mereka yang tidak rmasuk kriteria ini digugurkan dari proses pengolahan data lebih lanjut.

Lebih dari 1.700 paket kuesioner disebarkan melalui surat atau diantar langsung. Cakupan area geografisnya adalah Indonesia. Proses penyebaran sampai di tangan para partisipan mengikuti birokrasi organisasi bank yang bersangkutan. Sebelum proses penyebaran kuesioner dilakukan, tim peneliti menghubungi para pejabat bank untuk meminta ijin penelitian dan bantuan penyebaran serta pengumpulan kuesioner yang telah diisi. Kuesioner pada umumnya dikirim ke Bagian Umum atau kepada orang yang ditunjuk untuk membantu penelitian ini. Amplop kosong disediakan untuk setiap paket kuesioner sehingga 
kerahasiaan data bisa relatif terjamin. Setelah melalui proses seleksi, sebanyak 1.122 kuesioner bisa digunakan untuk penelitian ini.

\section{Analisis}

Untuk menguji hipotesis penelitian, alat statistik yang digunakan adalah regresi berganda. Variabel-variabel dengan skala nominal diperlakukan sebagai variabel kontrol. Dengan demikian, regresi dilakukan dengan memasukkan variabel KPK, KKP, intensi keluar, dan usia. Jenis kelamin, status pernikahan dan dukungan domestik dimasukkan pada setiap tahap analisis sebagai variabel kontrol.

Perangkat lunak SPSS 17 digunakan untuk melakukan analisis hubungan antar variabel. Deskripsi statistik juga dipaparkan untuk memberi gambaran demografis responden maupun sebaran respon atas pertanyaan-pertanyaan yang diajukan.

\section{HASIL PENELITIAN}

Partisipan penelitian ini mayoritas laki-laki (54\%). Namun jumlah perempuan juga cukup banyak (46\%). Walaupun jumlah partisipan laki laki lebih banyak dibanding perempuan, selisih $8 \%$ diharapkan tidak mengganggu hasil analisis. Dari sisi usia, lebih dari $75 \%$ partisipan berusia relatif muda, yaitu di bawah 45 tahun. Mayoritas partisipan menikah (77\%). Dari total 1.122 partisipan, sebanyak 763 (68\%) memiliki dukungan domestik, yaitu memiliki keluarga, teman atau pembantu rumah tangga yang siap melakukan aktivitas-aktivitas domestik seperti mengasuh anak, memasak, mencuci pakaian dan membersihkan rumah. Data partisipan dipresentasikan pada Tabel 1.

Tingkat KPK yang dialami oleh partisipan secara umum lebih tinggi dibandingkan dengan tingkat KKP. Rata-rata tingkat KPK adalah 2,70 sedangkan tingkat KKP adalah 2,32. Perbedaan tingkat KPK dan KKP secara statistik signifikan.

Tabel 2 di bawah menjelaskan rata-rata tingkat KPK, KKP dan intensi keluar. Perempuan memiliki rata-rata tingkat KPK lebih rendah dan KKP yang sedikit lebih tinggi dibandingkan dengan laki-laki. Laki-laki memiliki rata-rata tingkat intensi keluar yang lebih tinggi dibandingkan dengan perempuan. Dibandingkan dengan variabel lain, selisih angka rata-rata intensi keluar laki-laki dan perempuan cukup besar, yaitu 0,055 .

Tabel 3 menunjukkan hubungan antar variabel dalam penelitian ini. Regresi pertama menunjukkan hubungan pengaruh jenis kelamin dan usia pada KPK. Dengan berdasar pada nilai signifikansi sebesar $\mathrm{p}=0,05$, pengaruh jenis kelamin, usia dan dukungan domestik (domestik) pada KPK secara statistik tidak signifikan. Status pernikahan berpengaruh positif (dengan nilai standardized beta 0,092) dan signifikan $(0,007)$ pada KPK. Artinya, mereka yang menikah memiliki tingkat KPK lebih tinggi dibandingkan dengan mereka yang belum menikah. Dengan demikian, hipotesis H1a, H2a, dan H4a tidak terdukung. Hanya hipotesis H3a yang didukung secara statistik.

Tabel 1: Statistik deskriptif untuk variabel-variabel demograpik (jenis kelamin, usia, status pernikahan, jumlah anak)

\begin{tabular}{lll}
\hline \multicolumn{1}{c}{ Karakteristik Demografik } & \multicolumn{1}{c}{ Frekuensi } & $\%$ \\
\hline Jumlah Responden & $\mathrm{N}=1122$ & $100 \%$ \\
Jenis kelamin & Laki-laki $=606$ & $54 \%$ \\
& Perempuan $=516$ & $46 \%$ \\
Usia(tahun) & di bawah $25=64$ & $5,7 \%$ \\
& $25-34=479$ & $42,69 \%$ \\
& $35-44=439$ & $39,13 \%$ \\
& $45-55=136$ & $12,12 \%$ \\
Status pernikahan & di atas 55=4 & $0,36 \%$ \\
& Tidak emikah $=260$ & $23 \%$ \\
Dukungan domestik & Menikah $=862$ & $77 \%$ \\
& Ada $=763$ & $68 \%$ \\
& Tidak Ada $=359$ & $32 \%$ \\
\hline
\end{tabular}


Tabel 2: Rata-rata Tingkat KPK KKP dan Intensi Keluar

\begin{tabular}{lccc}
\hline & Perempuan & Laki-laki & Selisih \\
\hline KPK & 2,688 & 2.711 & $-0,023$ \\
KKP & 2,320 & 2.312 & 0,008 \\
Intensi Keluar & 2,670 & 2.725 & $-0,055$ \\
\hline
\end{tabular}

Tabel 3: Ringkasan Hasil Analisis Regresi Pengaruh Faktor Demografik Terhadap KKP

\begin{tabular}{|c|c|c|c|c|}
\hline Variabel & $\begin{array}{c}\text { Jenis } \\
\text { Kelamin }\end{array}$ & Usia & $\begin{array}{c}\text { Status } \\
\text { Pernikahan }\end{array}$ & $\begin{array}{l}\text { Dukungan } \\
\text { Domestik }\end{array}$ \\
\hline \multicolumn{5}{|l|}{ KPK $\leftarrow$ Jenis Kelamin, Usia } \\
\hline \multicolumn{5}{|l|}{ Signifikansi $=0,933$} \\
\hline Koefisien beta (standardized) & $-0,008$ & 0,006 & & \\
\hline Signifikansi & 0,797 & 0,838 & & \\
\hline \multicolumn{5}{|l|}{$\mathrm{KPK} \leftarrow$ Usia } \\
\hline Nilai $F$ & & 0,072 & & \\
\hline Signifikansi & & 0,788 & & \\
\hline Koefisien beta (standardized) & & 0,008 & & \\
\hline Signifikansi & & 0,788 & & \\
\hline \multicolumn{5}{|l|}{$\mathrm{KPK} \leftarrow$ Status Pernikahan, Usia } \\
\hline \multicolumn{5}{|l|}{ Nilai $F=3,741$} \\
\hline \multicolumn{5}{|l|}{ Signifikansi $=0,024^{*}$} \\
\hline Koefisien beta (standardized) & & $-0,036$ & $0,092 *$ & \\
\hline Signifikansi & & 0.293 & 0,007 & \\
\hline \multicolumn{5}{|c|}{ KPK $\leftarrow$ Dukungan Domestik, Usia } \\
\hline \multicolumn{5}{|l|}{ Nilai $F=0,183$} \\
\hline \multicolumn{5}{|l|}{ Signifikansi $=0,833$} \\
\hline Koefisien beta (standardized) & & 0,009 & & 0,016 \\
\hline Signifikansi & & 0,773 & & 0,558 \\
\hline Variabel & $\begin{array}{c}\text { Jenis } \\
\text { Kelamin }\end{array}$ & Usia & $\begin{array}{c}\text { Status } \\
\text { Pernikahan }\end{array}$ & $\begin{array}{c}\text { Dukungan } \\
\text { domestik }\end{array}$ \\
\hline \multicolumn{5}{|l|}{ KKP $\leftarrow$ Jenis Kelamin, Usia } \\
\hline \multicolumn{5}{|l|}{ Nilai $F=0,033$} \\
\hline \multicolumn{5}{|l|}{ Signifikansi $=0,968$} \\
\hline Koefisien beta (standardized) & 0,006 & 0,007 & & \\
\hline Signifikansi & 0,857 & 0,828 & & \\
\hline \multicolumn{5}{|l|}{ KKP $\leftarrow$ Usia } \\
\hline Nilai $F$ & & 0,033 & & \\
\hline Signifikansi & & 0,856 & & \\
\hline Koefisien beta (standardized) & & 0,005 & & \\
\hline Signifikansi & & 0,856 & & \\
\hline \multicolumn{5}{|l|}{ KKP $\leftarrow$ Status Pernikahan, Usia } \\
\hline \multicolumn{5}{|l|}{ Nilai $F=3,257$} \\
\hline \multicolumn{5}{|l|}{ Signifikansi $=0,039^{*}$} \\
\hline Koefisien beta (standardized) & & $-0,035$ & $0,086^{*}$ & \\
\hline Signifikansi & & 0,296 & 0,011 & \\
\hline \multicolumn{5}{|c|}{ KKP $\leftarrow$ Dukungan Domestik, Usia } \\
\hline \multicolumn{5}{|l|}{ Nilai $F=1,293$} \\
\hline \multicolumn{5}{|l|}{ Signifikansi $=0,275$} \\
\hline Koefisien beta (standardized) & & 0,007 & & 0,048 \\
\hline Signifikansi & & 0,812 & & 0,110 \\
\hline
\end{tabular}


Tabel 5: Ringkasan Hasil Analisis Regresi Pengaruh Faktor Demografik TerhadapIntensi Keluar

\begin{tabular}{|c|c|c|c|c|}
\hline Variabel & $\begin{array}{c}\text { Jenis } \\
\text { Kelamin }\end{array}$ & Usia & $\begin{array}{c}\text { Status } \\
\text { Pernikahan }\end{array}$ & $\begin{array}{c}\text { Dukungan } \\
\text { domestik }\end{array}$ \\
\hline \multicolumn{5}{|c|}{ Intensi Keluar $\leftarrow$ Jenis Kelamin, Usia } \\
\hline \multicolumn{5}{|c|}{ Nilai $\mathrm{F}=3,213^{*}$} \\
\hline \multicolumn{5}{|l|}{ Signifikansi $=0,041$} \\
\hline \multicolumn{5}{|l|}{ Koefisien beta (standardized) } \\
\hline \multirow[t]{2}{*}{ Signifikansi } & $-0,038$ & $-0,074 *$ & & \\
\hline & 0,212 & 0,015 & & \\
\hline \multicolumn{5}{|l|}{ Intensi Keluar $\leftarrow$ Usia } \\
\hline Nilai F & & $4,864 *$ & & \\
\hline Signifikansi & & 0,028 & & \\
\hline Koefisien beta (standardized) & & $-0,066^{*}$ & & \\
\hline Signifikansi & & 0,028 & & \\
\hline \multicolumn{5}{|c|}{ Intensi Keluar $\leftarrow$ Status Pernikahan, } \\
\hline \multicolumn{5}{|l|}{ Usia } \\
\hline \multicolumn{5}{|l|}{ Nilai $F=2,459$} \\
\hline \multicolumn{5}{|l|}{ Signifikansi $=0,086$} \\
\hline Koefisien beta (standardized) & & $-0,062$ & $-0,008$ & \\
\hline Signifikansi & & 0,068 & 0,811 & \\
\hline \multicolumn{5}{|l|}{ Intensi Keluar $\leftarrow$ Dukungan } \\
\hline \multicolumn{5}{|l|}{ Domestik, Usia } \\
\hline \multicolumn{5}{|l|}{ Nilai $F=2,703$} \\
\hline \multicolumn{5}{|l|}{ Signifikansi $=0,067$} \\
\hline Koefisien beta (standardized) & & $-0,067 *$ & & $-0,022$ \\
\hline Signifikansi & & 0,026 & & 0,461 \\
\hline
\end{tabular}

Variabel KKP dihipotesiskan dipengaruhi secara positif oleh berbagai variabel demografik. Hasil pengetesan secara statistik terhadap hipotesis-hipotesis tersebut dipaparkan pada Tabel 4. Analisis tersebut menunjukkan hasil yang mirip dengan analisis sebelumnya. Hanya status pernikahan yang secara statistik signifikan $(0,011)$ berpengaruh positif (dengan nilai standardized beta 0,086) pada KKP. Artinya, mereka yang menikah mengalami KKP lebih tinggi dibandingkan dengan mereka yang belum menikah. Dengan demikian $\mathrm{H} 3 \mathrm{~b}$ yang secara statistik terdukung dan $\mathrm{H} 1 \mathrm{~b}$, $\mathrm{H} 2 \mathrm{~b}, \mathrm{H} 4 \mathrm{~b}$ tidak terdukung.

Pengaruh variabel demografik pada intensi keluar dipaparkan di Tabel 5 . Berdasarkan pada tabel tersebut terlihat bahwa usia berpengaruh secara signifikan terhadap intensi keluar. Artinya, semakin muda usia, tingkat intensi keluar makin tinggi. Temuan ini berbeda dari ekspektasi hipotesis. Walaupun berpengaruh secara signifikan (baik pada saat diregresikan menggunakan bersama-sama dengan variabel jenis kelamin maupun diregresikan secara parsial), pengaruh usia pada intensi keluar memiliki arah yang terbalik. Dengan demikian, seluruh hipotesis (H1c, H2c, $\mathrm{H} 3 \mathrm{c}$ dan $\mathrm{H} 4 \mathrm{c}$ ) tidak terdukung.

\section{DISKUSI TEMUAN PENELITIAN}

Hasil penelitian menunjukkan bahwa jenis kelamin tidak berpengaruh positif (justru berpengaruh negatif) pada KPK namun pengaruh tersebut tidak signifikan (beta = $0,008, p=0,797>0,05)$. Pengaruh jenis kelamin pada KKP positif namun juga tidak signifikan (beta $=0,006, \mathrm{p}=0,857>0,05$ ). Sedangkan pengaruh jenis kelamin pada intensi keluar adalah negatif dan tidak signifikan secara statistik (beta $=-0,038, \mathrm{p}=0,212>$ 0,05). Hipotesis penelitian utama $\mathrm{H} 1$ dan hipotesis turunannya (H1a, H1b dan H1c) secara statistik tidak terdukung oleh data.

Secara deskriptif, laki-laki mengalami KPK lebih tinggi $(2,71)$ dibanding perempuan $(2,69)$. Namun perbedaan tersebut tidak signifikan secara statistik. Sebaliknya, perempuan mengalami tingkat KKP yang sedikit lebih tinggi dibanding laki-laki (2,32 dibanding 2,31). Secara statistik perbedaan 
tersebut juga tidak signifikan. Dalam hal intensi keluar, laki-laki lebih kuat $(2,73)$ dibandingkan perempuan (2,67). Walaupun demikian, perbedaan tersebut tidak signifikan secara statistik.

Tidak terdukungnya hipotesis oleh data penelitian menarik untuk dikaji. Tidak seperti dugaan semula, laki-laki dan perempuan mengalami tingkat konflik pekerjaan dan keluarga yang relatif seimbang. Kondisi ini mungkin disebabkan oleh adanya niat yang kuat, baik laki laki maupun perempuan, untuk bekerja sehingga mengesampingkan persepsi sosial tradisonal atas peran laki-laki dan perempuan. Kemungkinan lain adalah adanya pengetahuan yang relatif sama atas kondisi kerja, baik yang didapat melalui realistic job preview maupun proses lain. Tingkat pengetahuan atas pekerjaan yang relatif baik menghasilkan kesiapan diri menghadapi berbagai kondisi kerja dan keluarga yang baik pula. Hal-hal tersebut mungkin juga mengakibatkan adanya intensi keluar yang juga relatif sama. Temuan ini relatif sama dengan beberapa penelitian yang dilakukan menggunakan konteks negara Barat bahwa jenis kelamin tidak signifikan berpengaruh pada konflik pekerjaan dan keluarga serta intensi keluar (Cinamon and Rich, 2000; Duxbury and Higgins, 1991; Gutek, Searle and Klepa, 1991; Greenhaus, Parasuraman and Collins, 2001).

Usia berpengaruh positif pada KPK namun pengaruh tersebut tidak signifikan secara statistik (beta $=0,008, p=0,788>0,05$ ) dan KKP(b eta $=0,005, p=0,856>0,05)$. Temuan ini juga tidak sesuai dengan ekspektasi. Berkaitan dengan perjalanan karir seseorang, semakin tua ada kebutuhan yang lebih tinggi untuk menyeimbangkan antara tuntutan pekerjaan dan keluarga sehingga semakin bertambah usia maka pengalaman konflik pekerjaan dan keluarga makin meningkat. Namun, data penelitian ini tidak mendukung ekspektasi tersebut.

Temuan ini menunjukkan bahwa walaupun semakin bertambah usia tingkat konflik pekerjaan dan keluarga juga makin meningkat namun pengaruh usia pada konflik pekerjaan dan keluarga (baik KPK maupun KKP) tidak signifikan secara statistik. Kondisi ini mungkin disebabkan oleh proses adaptasi yang sudah mapan sehingga konflik yang terjadi dapat dikelola dengan baik.
Berbeda dengan tingkat konflik pekerjaan dan keluarga, usia berhubungan secara negatif dan signifikan terhadap intensi keluar (beta $=-0,066, p=0,028<0,05)$. Artinya, semakin bertambah usia keinginan untuk keluar semakin rendah. Kondisi ini, sekali lagi, mungkin disebabkan oleh proses adaptasi yang sudah mapan. Proses adaptasi mungkin juga mencakup ekspektasi pada pekerjaan. Proses adaptasi yang sukses menghasilkan ekspektasi yang terpenuhi sehingga menumbuhkan keterikatan pada pekerjaan, baik keterikatan pada teman kerja, pekerjaan itu sendiri maupun organisasi dan dampak selanjutnya adalah menurunnya keinginan untuk keluar. Selain proses adaptasi, benefits yang didapat oleh karyawan mungkin bertambah seiring dengan semakin seniornya orang tersebut. Dengan demikian, semakin bertambah usia seseorang mungkin menjadi lebih nyaman di pekerjaannya atau di organisasi tempat dia bekerja. Semakin bertambah usia menjadikan karyawan semakin tersosialisasi dengan berbagai aspek organisasional sehingga juga makin cocok dengan organisasi (Cable and Parsons, 2001), semakin lekat pada pekerjaannya (Allen, 2006) dan dampak selanjutnya adalah menurunnya tingkat intensi keluar. Hal ini juga didukung oleh data deskriptif yang secara umum menggambarkan semakin bertambah usia, intensi keluarnya semakin rendah. Temuan ini sejalan dengan hasil riset Griffeth, Hom and Gaertner (2000).

Status pernikahan secara positif dan signifikan berpengaruh pada KPK( beta = $0,092, \mathrm{p}=0,007<0,05)$ dan $\mathrm{KKP}($ beta $=$ $0,086, p=0,011<0,05)$. Data deskriptif menunjukkan bahwa karyawan yang belum menikah merasakan rata-rata tingkat KPK yang lebih rendah $(2,54)$ dibandingkan dengan mereka yang sudah menikah $(2,75)$. Rata-rata tingkat KKP yang dialami oleh karyawan yang belum menikah juga lebih rendah $(2,19)$ dibandingkan dengan karyawan yang sudah menikah (2,35). Temuan ini sesuai dengan ekspektasi. Pernikahan menyebabkan seseorang harus membagi waktu, sumberdaya dan energinya untuk dua peran yang berbeda. Penggunaan waktu, sumberdaya dan energi pada satu domain menyebabkan gangguan pada domain yang lain karena sifat waktu, sumberdaya dan energi tersebut terbatas (Greenhaus and Beutell, 1985). Walaupun pernikahan telah menyebabkan terjadinya 
konflik pekerjaan dan keluarga yang secara statistik signifikan, tetapi pernikahan ternyata tidak berpengaruh secara positif dan signifikan pada intensi keluar (beta $=-0,008, \mathrm{p}=0,811$ > $0,05)$. Konflik yang dialami mungkin masih dalam batas toleransi. Mungkin juga konflik pekerjaan dan keluarga yang dialami justru dipersepsikan sebagai indikasi adanya kemajuan karir yang menguntungkan keluarga sehingga tidak perlu menimbulkan niat untuk mencari pekerjaan/kegiatan alternatif (Hofstede, Hofstede \& Minkov, 2010). Lebih lanjut, data deskriptif menunjukkan tingkat intensi keluar karyawan yang belum menikah sedikit lebih tinggi $(2,79)$ dibandingkan dengan mereka yang sudah menikah $(2,67)$. Perbedaan ini secara statistik tidak signifikan.

Dukungan domestik berpengaruh positif pada KPK namun pengaruh tersebut secara statistik tidak signifikan (beta $=0,016, \mathrm{p}$ $=0,558>0,05)$. Temuan yang sama juga terjadi pada pengaruh dukungan domestik pada KKP beta $=0,048, p=0,110>0,05)$. Temuan ini tidak sesuai dengan ekspektasi. Karyawan yang memiliki dukungan domestik, baik yang berasal dari keluarga, teman maupun pembantu rumah tangga, mengalami KPK sedikit lebih rendah $(2,69)$ dibandingkan dengan mereka yang tidak memiliki dukungan domestik $(2,72)$. Demikian juga dengan KKP. Mereka yang memiliki dukungan domestik mengalami KKP yang lebih rendah. Namun, perbedaan tersebut secara statistik tidak signifikan. Kondisi ini, sekali lagi, mungkin dikarenakan adanya antisipasi yang baik atas situasi pekerjaan dan keluarga sebagai akibat dari pengetahuan yang baik atas pekerjaannya, niat yang kuat untuk bekerja atau sebab lain yang membuat seseorang berusaha mengelola dirinya dengan efektif, baik ada dukungan domestik maupun tidak.

Dukungan domestik juga tidak berpengaruh positif dan signifikan pada intensi keluar (beta $=-0,022, p=0,461>0,05$ ). Sesuai dengan data penelitian, tingkat KPK dan KKP karyawan yang tidak memiliki dukungan domestik hanya sedang, tidak cukup kuat menumbuhkan intensi keluar karyawan. Mereka yang memiliki dukungan domestik, usianya relatif lebih tua dibandingkan dengan mereka yang tidak memiliki dukungan domestik. Tetapi rata-rata usia tersebut hanya berselisih sedikit $(35,16$ tahun dibanding 34,53 tahun). Dari data usia ini dapat diperkirakan bahwa usia karyawan yang memiliki dukungan domestik bervariasi. Demikian juga dengan mereka yang tidak memiliki dukungan domestik. Sebaran usia mereka yang memiliki dukungan domestik dan yang tidak memiliki dukungan domestik relatif sama sehingga menyebabkan pengalaman di tempat kerja dan di rumah tangga relatif sama pula. Pengalaman tersebut tidak terpengaruh oleh dukungan domestik. Hal ini berbeda dengan penjelasan terdahulu dimana semakin senior usia seseorang intensi keluarnya menurun.

\section{SIMPULAN}

Tujuan utama penelitian ini adalah untuk meneliti peran variabel demografik penting yang dipilih, yaitu jenis kelamin, usia, status pernikahan, dan dukungan domestik dalam konflik pekerjaan-keluarga, konflik keluargapekerjaan, dan intensi keluar. Hasil penelitian membuktikan bahwa variabel yang memiliki pengaruh secara signifikan terhadap munculnya konflik pekerjaan-keluarga dan konflik keluarga-pekerjaan adalah status pernikahan, sementara variabel-variabel lain, yaitu jenis kelamin, usia, dan dukungan domestik secara statistik tidak terbukti menjadi penyebab munculnya konflik pekerjaan-keluarga dan konflik keluarga-pekerjaan. Untuk intensi keluar, variabel yang terbukti secara statistik signifikan berpengaruh adalah usia. Variabelvariabel lain, yaitu jenis kelamin, status pernikahan, dan dukungan domestik tidak terbukti berpengaruh pada intensi keluar.

Variabel status pernikahan berpengaruh positif pada konflik pekerjaan-keluarga, artinya mereka yang menikah mengalami tingkat konflik pekerjaan-keluarga yang lebih tinggi dibandingkan dengan mereka yang tidak menikah. Sedangkan usia berpengaruh negatif pada intensi keluar, dengan semakin bertambahnya usia keinginan keluar dari perusahaan justru semakin rendah.

Hasil penelitian ini diharapkan dapat memberikan kontribusi bagi ilmu pengetahuan melalui dua cara. Pertama, dapat memberikan informasi praktikal untuk membantu para manajer membangun kebijakan-kebijakan dalam bidang sumberdaya manusia yang merefleksikan isu-isu demografik, sepertia usia, jenis kelamin, status pernikahan dan dukungan 
domestik dalam hubungannya dengan konflik pekerjaan dan keluarga dan intensi keluar. Kedua, penelitian dengan konteks Indonesia ini diharapkan dapat menambah pengetahuan yang ada saat ini yang cenderung lebih banyak mengambil konteks Barat.

Penelitian ini memiliki beberapa keterbatasan yang perlu diperhatikan. Beberapa hipotesis tidak terdukung. Walaupun secara teoritik dapat dijelaskan, namun eksplorasi lebih dalam perlu dilakukan untuk menemukan alasan kontekstual yang lebih spesifik.

Generalisasi hasil penelitian ini perlu juga dilakukan secara hati-hati. Karakteristik industri perbankan mungkin berbeda dari industri lain. Mengingat jumlah karyawan perempuan relatif banyak, industri perbankan mungkin lebih ramah terhadap perempuan (maupun laki-laki) sehingga jenis kelamin bukan merupakan isu penting yang harus mendapat perhatian khusus dalam kebijakan organisasional.

Status pernikahan tidak dilengkapi dengan jumlah anak maupun umur anak (jika partisipan sudah memiliki anak). Jumlah dan umur anak di berbagai penelitian (misalnya Greenhaus and Beutell, 1985) ditemukan berpengaruh pada konflik pekerjaan dan keluarga. Oleh karena itu, penelitian lebih lanjut perlu melengkapi variabel demografik dengan jumlah dan umur anak yang dimilikinya.

\section{DAFTAR PUSTAKA}

Allen, DG. 2006. Do organizational socialization tactics influence newcomer embeddedness and turnover?. Journal of Management. 32 (2). 237-56.

Bergiel, EB., VQ. Nguyen., BF. Clenney and GS. Taylor. 2009. Human resources practices, job embeddedness and intention to quit. Managerial Research News. 32 (3). 205-19.

Breukelen, WV., RVD. Vlist and H. Steensma. 2004. Voluntary employee turnover: combining variables from the 'traditional' turnover literature with the theory of planned behavior. Journal of Organizational Behavior. 25 (7). 893914.
Blau, F., M. Ferber and A. Winker. 1998. The economics of women, men and work, 3rd ed. Upper Saddle River. New Jersey. Prentice Hall.

Byron, K. 2005. A meta-analytic review of work-family conflict and its antecedents. Journal of Vocational Behavior. 67. 169-98.

Cable, DM. and CK. Parsons. 2001. Socialization tactics and person-organization fit. Personnel Psychology. 54 (1). 1-23.

Cinamon, RG. and Y. Rich. 2002. Gender differences in the importance of work and family roles: implications for work-family conflict. Sex Role. 47 (1112). 531-41.

Cohen, S. and SL. Syme. 1985. Social support and health. Academic Press, Inc.

Cooke, RA. and D.M. Rousseau. 1984. Stress and strain from family roles and workroles. Journal of applied psychology. 69 (2). 252-60.

Dess, GG. and JD. Shaw. 2001. Voluntary turnover, social capital, and organizational performance. The Academy of Management Review. 26 (3). 446-56.

Duxbury, L. and C. Higgins. 1991. Gender differences in work-family conflict. Journal of Applied Psychology. 76 (1). 60-74.

Eby, LT., WJ. Casper., A. Lockwood., C. Bordeaux and A. Brinley. 2005. Work and family research in IO/OB: content analysis and review of the literature (1980-2002). Journal of Vocational Behavior. 66. 124-97.

Friedman, SD. and JH. Greenhaus. 2000. Work and family-Allies or enemies?. New York. Oxford University Press.

Frone, MR., M. Russell and CL. Cooper. 1997. Relation of work-family conflict to health outcomes: a four year longitudinal study of employed parents. Journal of Occupational and Organizational Psychology. 70 (4). 325-35.

Goodstein, JD. 1994. Institutional pressures and strategic responsiveness: employer 
involvement in work-family issues. Academy of Management Journal. 37 (2). 350-382.

Gordon, JR. and KS. Whelan-Berry. 2007. The relationship among work-family conflict and enhancement, organizational culture and work outcomes for older working women. Journal of occupational health psychology. 12. 350-364.

Greenhaus, JH. And NJ. Beutell. 1985. Source of conflict between work and family roles. Academy of Management Review. 10 (1). 76-88.

Greenhaus, JH., S. Parasuraman and KM. Collins. 2001. Career involvement and family involvement as moderators of relationships between work-family conflict and withdrawal from a profession. Journal of Occupational Health Psychology. 6 (2). 91-100.

Greenhaus, JH. and GN. Powell. 2006. When work and family are allies: a theory of workfamily enrichment. Academy of Management Review. 31 (1). 72-92.

Griffeth, RW. PW. Hom and S. Gaertner. 2000. A meta-analysis of antecedents and corrkates of employee turnover: update, moderator tests, and research implications for the next millennium. Journal of Management. 26 (3). 46388.

Guimaraes, T. And M. Igbaria. 1992. Determinants of turnover intentions: comparing IC and IS personnel. Information Systems Research. 3 (3). 273-303.

Gutek, BA., S. Searle and L. Klepa. 1991. Rational versus gender role explanations for work-family conflict. Journal of Applied Psychology. 76 (4). 560-8.

Hammer, LB., JC. Cullen, MB. Neal, RR. Sinclair and MV. Shafiro. 2005. The Longitudinal effects of work-family conflict and positive spillover on depressive symptoms among dualearner couples', Journal of Occupational Health Psychology. 10(2). 13854.
Hayes, LJ., L. O'Brien-Pallas, C. Duffield, J. Shamian, J. Buchan, F. Hughes, HKS. Laschinger, N. North and PW. Stone. 2006. Nurse turnover: a literature review. International Journal of Nursing Studies. 43.

Hendrickson, R. 2000. What does the future hold for health care, elder care, and long-term care coverage for workers and their families?. Perspectives on Work. 4. 2. 16-17.

Hofstede, G. 2001. Geert Hofstede cultural dimension. itim International. June 15, 2010.

Hofstede, G., GJ. Hofstede and M. Minkov. 2010. Cultures and organizations: software of the mind: intercultural cooperation and its importance for survival. 3rd ed. New York. McGrawHill.

ILO. 2006. Isu-isu perempuan dan jender di organisasi serikat pekerja/buruh di Indonesia, Organisasi Perburuhan Internasional, Jakarta. http://www.ilo.org/public/indonesia/reg ion/asro/jakarta/download/jendersb.pdf .. Retrieved November 15, 2010.

Ilwan, H. and MS. Widodo. 2008. Musim berebut bankir pintar. Gatra. 45. September, 18.

Kinnnen, U., S. Geurts and S. Mauno. 2004. Work-to-family conflict and its relationship with satisfaction and wellbeing: a one-year longitudinal study on gender differences. Work \& Stress. 18 (1). 1-22.

Kossek, EE. And C. Ozeki. 1999. Bridging the work-family and productivity gap: a literature review. Community, Work \& Family. 2 (1). 7-32.

Koys, DJ. 2001. The effects of employee satisfaction, organizational citizenship behavior, and turnover on organizational effectiveness: a unit-level, longitudinal study. Personnel Psychology. 54. 101-14. 
Kreitner, R., and A. Kinicki. 2010. Organizational Behavior, $9^{\text {th }}$ ed. Boston. Irwin McGraw Hill.

Lambert, E.G., S. Pasupuleti. TC. Tolar. M. Jennings and D. Backer. 2006. The impact of work-family conflict on social work and human service worker job satisfaction and organizational commitment: An exploratory study. Administration in Social Work. 30. 145-159.

Lingard, H. and V. Francis. 2006. Does a supportive work environment moderate the relationship between work-family conflict and burnout among construction professionals. Construction Management and Economics. 24. 185-196.

Lu, L., R. Gilmour. S-F. Kao and M-T. Huang. 2006. A cross-cultural study of work/family demands, work/family conflict and well-being: the Taiwanese vs British. Career Development International. 11 (1). 9-27.

Maertz, CP. and RW. Griffeth. 2004. Eight motivational forces and voluntary turnover: a theoretical synthesis with implications for research. Academy of Management Journal. 30 (5). 667-83.

Mesmer-Magnus, JR., and C. Viswervaran. 2005. Convergence between measures of work to-family and family-to-work conflict: a meta-analytic examination. Journal of Vocational Behavior. 67. 215-32.

Michaels, CE., and PE. Spector. 1982. Causes of employee turnover: a test of the Mobley, Griffeth, Hand, and Meglino model. Journal of Applied Psychology. 67 (1). 53-9.

Milliken, FJ., LL. Martins and H. Morgan. 1998. Explaining organizational responsiveness to work-family issues: The role of human resource executives as issue interpreters. Academy of Management Journal. 41 (5). 580-592.

Mitchell, TR., BC. Holtom and TW. Lee. 2001. How to keep your best employees: developing an effective retention policy. Academy of Management Executive. 15 (4). 96-108.

Mitchell, TR., BC. Holtom. TW. Lee. CJ. Sablynski and M. Erez. 2001. Why People Stay: Using Job Embeddedness to Predict Voluntary Turnover. Academy of Management Journal. 44 (6). 1102-21.

Mobley, WH., RW. Griffeth. HH. Hand and BM. Meglino. 1979. Review and conceptual analysis of the employee turnover process. Psychological Bulletin. 86 (3). 493-522.

Mobley, WH., SO. Horner and AT. Hollingsworth. 1978. An evaluation of precursors of hospital employee turnover. Journal of Applied Psychology. 63 (4). 408-14.

Netemeyer, RG., JS. Boles and R. McMurrian. 1996. Development and validation of workfamily conflict and family-work conflict scales. Journal of Applied Psychology. 81 (4). 400-10.

Oyserman, D., HM. Coon and M. Kemmelmeier. 2002. Rethinking individualism and collectivism: evaluation of theoretical assumptions and meta-analysis. Psychological Bulletin. 128 (1). 3-72.

Pambudi, TS. 2007. Sebuah laporan dari karyawan. SWA Sembada. Swa. March 29.

Parasuraman, S., JH. Greenhaus and CS. Granrose. 1992. Role stressors, social support, and well-being among two career couples. Journal of Organizational Behavior. 13. 339-356.

Pasewark, WR. and RE. Viator. 2006. Sources of work-family conflict in the accounting profession. Behavioral Research in Accounting. 18. 147-65.

Pinkovitz, WH., J. Moskal and G. Green. 2004. How much does your employee turnover cost? http://www.uwex.edu/CES/cced/public at/turn.html. Retrieved September 11, 2006.

Price, JL. 2004. The development of a causal model of voluntary turnover. Innova- 
tive theory and empirical research on employee turnover. Greenwich. Information Age. 3-32.

Rahayu, EM. 2006. Perbankan: aduhai karena langka SDM andal. SWA Sembada. February 09.

Russ, FA. and KM. McNeilly. 1995. Links among satisfaction, commitment, and turnover intentions: the moderating effect of experience, gender, and performance. Journal of Business Research. 34. 57-65.

Siahaan, AY. 2003. The politics of gender and decentralization in Indonesia, Center for Policies Studies, Central European Universities and the Open Society Institute.

http://www.policy.hu/siahaan/research paper3.htm. Retrieved February 16, 2007.

Soetjipto, AW. 2004. Big party politics--still a man's world. FPOatSEAW Watch (ed.), Southeast Asian Women in Politics and Decision Making, Ten Years After Beijing: Gaining Ground?. Quezon City. FES Philippine Office and SEAWWatch. 38-82.

Spector, PE., CL. Cooper. SAY. Poelmans. TD. Allen. M. O'Driscoll. JI. Sanchez. OL. Siu. P. Dewe. P. Hart and L. Lu. 2004. A cross-national comparative study of work-family stressors, working hours, and well-being: China and Latin America versus the Anglo world. Personnel Psychology. 57. 119-42.

Spector, PE., TD. Allen. SAY. Poelmans. LM. Lapiere. CL. Cooper. M. O'Driscoll. JI. Sanchez. N. Abarca. M. Alexandrova. B. Beham. P. Brough. P. Ferreiro. G. Fraile. C-Q. Lu. L. Lu. I. MorenoVelazquez. M. Pagon. H. Pitariu. V. Salamatov. S. Shima. AS. Simoni. OL. Siu and M. Widerszal-Bazyl. 2007. Cross-national differences in relationships of work demands, job satisfaction, and turnover intentions with work-family conflict. Personnel Psychology. 60. 805-35.
Staines, GL. and P. O'Connor. 1980. Conflicts among work, leisure, and family roles. Monthly labour review. 103 (8). 35-39.

Steel, RP. and NK. Ovalle. 1984. A review and meta-analysis of research on the relationship between behavioral intentions and employee turnover. Journal of Applied Psychology. 69 (4). 673-86.

Steers, RM. and SR. Rhodes. 1978. Major influences on employee attendance: a process model. Journal of Applied Psychology. 63. 391-407.

Sugiarto, A. 2003. Bagaimana nasib perbankan kita setelah ditinggal IMF. Bank of Indonesia, Jakarta. November 14, 2010.

Thatcher, JB., LP. Stepina and RJ. Boyle. 2002. Turnover of information technology workers: examining empirically the influence of attitudes, job characteristics, and external markets. Journal of Management Information Systems. 19 (3). 231-61.

Van der Velde, MEG., CJH. Bossink and PGW. Jansen. 2005. Gender differences in the determinants of the willingness to accept an international assignment. Journal of Vocational Behavior. 66. 81-103.

Van der Velde, MEG., CJH. Bossink and PGW. Jansen. 2003. Gender differences in the influence of professional tenure on work attitudes. Sex Roles. 49 (3/4). 153-62.

Viega, JF. 1983. Toward understanding employee reluctance to participate in family friendly programs. Human management review. 14. 337-351.

Watson, CJ. 1981. An evaluation of some aspects of the Steers and Rhodes model of employee attendance. Journal of Applied Psychology. 66 (3). 385-9.

Watson-Wyatt. 2005a. WorkAsia 2004/2005: a study of employee attitudes in Asia, the keys to what Asian employees tick. Watson Wyatt Worldwide.

Watson-Wyatt. 2005b. WorkIndonesia 2004/2005: a study of employee atti- 
tudes in Indonesia, the keys to what makes Indonesian employees tick. Watson Wyatt Worldwide.

Wedhaswary, ID. 2008. Soal posisi laki perempuan, masyarakat kita sakit. Kompas. http://www.kompas.com/read/xml/200 8/11/08/11351231/soal.posisi.laki.pere mpuan.masyarakat.kita.sakit. Retrieved December 22, 2009.

Williams, LJ. and JT. Hazer. 1986. Antecedents and consequences of satisfaction and commitment in turnover models: a reanalysis using latent variable structural equation methods. Journal of Applied Psychology. 71 (2). 219-31.
Winasis, KW., P. Sanyoto. H. Gunawan and Windarto. 2007. Bajak-membajak makin marak. Majalah Trust. December, 31 - January, 6 .

Yang, N., CC. Chen. J. Choi and Y. Zou. 2000. Sources of work-family conflict: a sino-U.S. comparison of the effects of work and family demands. Academy of Management Journal. 43 (1). 113-23.

Yurnaldi. 2010. AS apresiasi demokratisasi di Indonesia.

http://internasional.kompas.com/read/2 010/10/19/22203838/AS.Apresiasi.De mokratisasi.di.Indonesia. Retrieved October 29, 2010. 